\title{
Uji Aktivitas Antibakteri Ekstrak Etanol Daun Suruhan (Peperomia pellucida L. Kunth) Terhadap Bakteri Pseudomonas aeruginosa ATCC 27853
}

\section{Antimicrobial Activity Test Of Ethanolic Leaves Extract of Suruhan (Peperomia pellucida L. Kunth) Against Pseudomonas aeruginosa ATCC 27833}

\author{
Desi Purwaningsih $^{1^{*}}$, Destik Wulandari ${ }^{1}$ \\ ${ }^{1}$ Program Studi S-1 Farmasi, Fakultas Farmasi, Universitas Setia Budi \\ Jalan Let. Jend. Sutoyo, Mojosongo, Surakarta, Jawa Tengah, Indonesia \\ Email:dhedez.dp@gmail.com *Penulis Korespondensi
}

\begin{abstract}
Pseudomonas aeruginosa ATCC 27833 is an opportunistic pathogenic bacterium that causes nosocomial infections in patients with septicemia, cystic fibrosis, burns, and wound infections that can lead to high mortality rates. Bacteria $P$. aeruginosa is reported to have resistance to several kinds of antibiotics. This can cause a long healing time and increase the risk of death. One of the efforts to overcome this problem is to take an alternative way, namely to use natural medicines based on plants. One of the plants that has potential as an antimicrobial is Suruhan (Peperomia pellucida L. Kunth). The purpose of this study was to determine the activity of Suruhan extracts in killing $P$. aeruginosa bacteria. The antibacterial test method used in this study is a dilution test to determine the Minimum Inhibitory Concentration (MIC) and Minimum Kill Concentration (CBC). The extracts made in 9 series of concentrations are $50,25,12.5,6.25,3.12,1.56,0.78,0.39$, and $0.19 \%$. The test results showed that the MIC value could not be determined because the mixture between the Suruhan leaf extracts and the bacterium $P$. aeruginosa was very turbid. The MBC value obtained from the antibacterial activity test of leaf extracts ordered against $P$. aeruginosa was $25 \%$.
\end{abstract}

Key words: antimicrobial, Peperomia pellucid, Pseudomonas aeruginosa, dilution

\begin{abstract}
Abstrak
Pseudomonas aeruginosa ATCC 27833 merupakan bakteri patogen oportunistik penyebab infeksi nosocomial pada pasien septikemia, sistik fibrosis, luka bakar, dan infeksi luka yang dapat menyebabkan tingkat mortilitas tinggi. Bakteri $P$. aeruginosa dilaporkan mengalami resistensi terhadap beberapa macam antibiotik. Hal tersebut dapat mengakibatkan lamanya waktu penyembuhan dan meningkatkan resiko kematian. Salah satu upaya untuk mengatasi permasalahan ini ialah dengan mengambil jalan alternatif menggunakan obat-obatan alami berbahan dasar tumbuhan. Salah satu tumbuhan yang memiliki potensi sebagai antimikroba adalah suruhan (Peperomia pellucida L. Kunth). Tujuan penelitian ini adalah untuk mengetahui aktivitas ekstrak daun suruhan dalam membunuh bakteri $P$. aeruginosa. Metode uji antibakteri yang digunakan dalam penelitian ini adalah uji dilusi untuk mengetahui Konsentrasi Hambat Minimum (KHM) dan Konsentrasi Bunuh Minimum (KBM). Ekstrak suruhan dibuat dalam 9 seri konsentrasi yaitu 50, 25, 12,5, 6,25, 3,12, 1,56, 0,78, 0,39, dan 0,19\%. Hasil uji menunjukkan nilai KHM yang tidak dapat ditentukan karena campuran ekstrak daun suruhan dan bakteri $P$. aeruginosa sangat keruh. Nilai KBM yang diperoleh dari uji aktivitas antibakteri ekstrak daun suruhan terhadap bakteri $P$. aeruginosa adalah sebesar $25 \%$.
\end{abstract}

Kata kunci: antibakteri, Peperomia pellucida, Pseudomonas aeruginosa, dilusi 


\section{Pendahuluan}

Pseudomonas aeruginosa ATCC 27833 merupakan bakteri patogen oportunistik penyebab infeksi nosokomial terutama pada pasien yang mengalami penurunan sistem imun(Vahdani et al., 2012). Angka insiden infeksi nosokomial yang disebabkan oleh bakteri $P$. aeruginosa terjadi sekitar $10-15 \%$ di dunia dan sekitar $10-20 \%$ pada unit perawatan intensif (ICU), biasanya terjadi pada pasien septikemia, sistik fibrosis, luka bakar, dan infeksi luka(Article et al., 2014). Gangguan kesehatan oleh $P$. aeruginosa seperti sepsis pneumonia, infeksi nosocomial yang meliputi $16 \%$ kasus pneumonia nosocomial, $12 \%$ kasus infeksi traktus urinarius, $10 \%$ kasus infeksi dalam aliran darah, dan $8 \%$ kasus infeksi luka operasi, (Pagani et al., 2005).

Upaya penanggulangan penyakit infeksi biasanya dilakukan dengan beberapa antibiotik seperti; seperti, penisilin, sefalosporin, isomiazid, kontrimoksazol, rifamisin (Radji et al., 2011). Bakteri $P$. aeruginosa dilaporkan mengalami resistensi terhadap berbagai jenis antibiotika. Menurut Rukmono \& Zuraida (2016) P. aeruginosa resisten terhadap 14 macam obat antibiotik seperti; ampisilin, eritromisin, amoksisilin, sefurosim, seftriason, gentamisin, tetrasiklin, sefadroksil, piperasilin, trimetroprim, dan tobramisin(Rukmono \& Zuraida, 2013). Resistensi bakteri terhadap antibiotik dapat mengakibatkan lamanya waktu penyembuhan, meningkatkan resiko kematian, memperbanyak carrier di masyarakat, memperbanyak bakteri yang resisten, dan memperpanjang masa rawat inap di rumah sakit, sehingga berakibat pada meningkatnya biaya pengobatan (Utami, 2002).

Berkembangnya resistensi obat serta meningkatnya keinginan konsumen terhadap obat-obatan dengan efek samping minimal mendorong para peneliti untuk mengembangkan obat antimikroba baru. Untuk mengatasi masalah ini salah satunya dengan mengambil jalan alternatif yaitu menggunakan obat-obatan alami berbahan dasar tumbuhan atau yang biasa disebut obat herbal. Salah satu jenis tumbuhan yang mempunyai potensi sebagai obat herbal adalah suruhan (Peperomia pellucida L. Kunth). Wei et. al (2011) melaporkan tanaman suruhan memiliki potensi sebagai antimikroba dengan adanya senyawa metabolit yang dihasilkan oleh tanaman tersebut seperti flafonoid, fenolik, saponin, dan triterpenoid(Wei et al., 2011). Berdasarkan hal tersebut, maka perlu dilakukan penelitian lebih lanjut terkait potensi ekstrak daun suruhan dalam menghambat pertumbuhan bakteri Pseudomonas aeruginosa ATCC 27833.

\section{Metode Penelitian}

\section{Alat dan Bahan}

Bahan yang digunakan dalam penelitian ini dalah daun suruhan, bakteri Pseudomonas aeruginosa ATCC 27833, media Muller Hinton Agar (MHA), Brain Brain Heart Infusion (BHI), Pseudomonas Selective Agar (PSA), Nutrient agar (NA), etanol 70\%, aquadest, DMSO 5\%, Ciprofloksasin, cat Gram A, Gram B, Gram C, dan Gram D.

Alat yang digunakan dalam penelitian ini adalah Erlenmeyer, lampu spirtus, pinset, gelas penyimpanan ekstrak, kertas saring, tabung ekstraksi , timbangan analitis, incubator, gelas beker, gelas ukur, pipet volume, cawan petri, tabung reaksi, inkas, jarum ose, rak tabung reaksi, mikroskop, batang pengaduk, autoklaf, penangas air, ayakan nomer 60, oven, seperangkat alat Rotary Evaporator.

\section{Prosedur Penelitian}

Penelitian ini dimulai dengan identifikasi tanaman suruhan yang dilakukan di Laboratorium Morfologi dan Sistematika Tumbuhan, fakultas Farmasi Universitas Setia Budi. Identifikasi dilakukan dangan cara mengamati ciri morfologi dari tanaman suruhan yang meliputi bagian bunga, batang, dan daunnya. Tujuan dilakukan identifikasi tersebut adalah untuk memastikan bahwa sampel yang digunakan dalam penelitian merupakan tanaman suruhan (Peperomia pellucida L. Kunth).

Pembuatan ekstrak daun Suruhan. Sebanyak $10 \mathrm{~kg}$ daun dari tumbuhan suruhan yang sudah diidentifikasi dibersihkan dari kotoran yang menempel dengan cara dicuci kemudian dikeringkan untuk mengurangi kadar air dari daun suruhan tersebut supaya tidak ditumbuhi oleh jamur dan bakteri. Daun suruhan yang sudah kering dan bersih tersebut kemudian dihaluskan dan diayak 
menggunakan ayakan nomer 60. Serbuk daun suruhan yang dihasilkan tersebut lalu diekstraksi menggunakan metode maserasi dengan etanol $70 \%$ sebagai pelarutnya, dengan perbandingan antara serbuk dan pelarut adalah 1:5. Proses maserasi dilakukan selama lima hari dan sesekali dilakukan pengadukan. Maserat yang telah didapatkan dari proses selama lima hari kemudian disaring dan dipisahkan dari pelarutnya dengan menggunakan vaccum evaporator pada suhu $50^{\circ} \mathrm{C}$ sehingga diperoleh ekstrak kental (Helmi et al., 2006).

\section{Identifikasi Bakteri}

Identifikasi bakteri dilakukan untuk mengetahui ciri morfologi maupun fisiologi dari bakteri yang akan digunakan. Ciri morfologi dapat diketahui dengan pewarnaan Gram. Diawali dengan pembuatan preparat smear dan ditetesi Gram A (kristal violet) yang kemudian didiamkan selama 1 menit sebelum dibilas dengan air mengalir. Dilanjutkan dengan ditetesi Gram B sebagai mordant (iodine) didiamkan selama 1 menit dan dibilas lagi dengan air mengalir, kemudian ditetesi dengan Gram C (alkohol 96\%) setetes demi setetes sampai tetesan alcohol menjadi jernih, dan diakhiri dengan ditetesi Gram D (safranin) diamkan selama 45 detik, dibilas dengan air mengalir, dikeringkan, dan diamati menggunakan mikroskop sampai perbesaran lensa objektif 100 kali(Fitri L, 2011). Identifikasi fisiologi dilakukan dengan cara menanam Pseudomonas aeruginosa ATCC 27833 pada media Pseudomonas Selective Agar (PSA)(Brooks, Geo F . Butel, Janet. Morse, 2004).

\section{Uji Aktivitas Antibakteri}

Kemampuan suatu senyawa untuk menghambat atau membunuh bakkteri dapat ditentukan dari penentuan Konsentrasi Hambat
Minimum (KHM) dan Konsentrasi Bunuh Minimum (KBM) dapat ditentukan dengan menggunakan metode pengenceran tabung (tube dilution method)(Pasril et al., 2014). Penelitian ini menggunakan 9 konsentrasi ekstrak etanol Peperomia pellucida L. Kunth yaitu 50, 25, 12,5, 6,25, 3,12, 1,56, 0,78, 0,39, dan $0,19 \%$ dimana dalam proses pembuatan konsetrasi 50\% menggunakan larutan DMSO $5 \%$, selanjutnya dilakukan pengenceran bertingkat dengan pengencer BHI. Digunakan juga 1 kelompok kontrol bakteri dan 1 kelompok kontrol bahan, sehingga dalam 1 kali uji dibutuhkan 11 tabung. 2 tabung digunakan untuk kontrol bakteri dan kontrol bahan, 9 tabung digunakan untuk perlakuan yang masing-masing tabung berisi ekstrak dengan variasi konsentrasi dari 50, 25, 12,5, $6,25,3,12,1,56,0,78,0,39$, dan 0,19\%, BHI dan suspensi bakteri. Masing-masing perlakuan dilakukan pengulangan sebanyak 3 kali (Wulandari \& Purwaningsih, 2016).

\section{Analisis Data}

Data konsentrasi hambat minimum (KHM) \& konsentrasi bunuh minimum (KBM) yang diperoleh dianalisis secara deskriptif dan ditampilkan dalam bentuk gambar dan tabel.

\section{Hasil dan Pembahasan}

\section{Determinasi dan pembuatan ekstrak daun suruhan}

Tanaman suruh-suruhan yang akan digunakan terlebih dahulu diidentifikasi di Laboratorium Morfologi dan Sistematika Tumbuhan Fakultas Farmasi Universitas Setia Budi Surakarta. 650 gr serbuk yang diperoleh kemudian diekstrak menggunakan etanol $70 \%$ sehingga didapat ektrak sebanyak 114 gr, dan nilai rendemen sebesar 17,53\%.

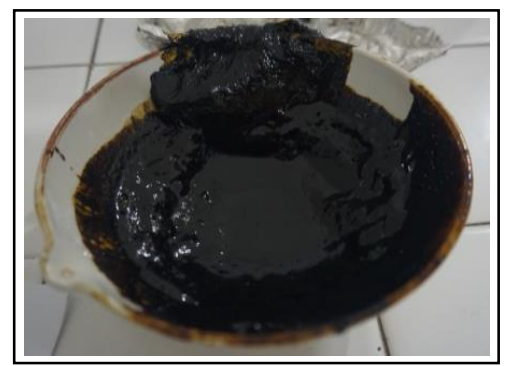

Gambar 1. Ekstrak kental daun suruhan, berwarna hijau kehitaman 


\section{Identifikasi Bakteri Uji}

Hasil pewarnaan Gram untuk Pseudomonas aeruginosa ATCC 27833 menunjukkan adanya warna merah pada sel bakteri dan bakteri terlihat berbentuk bacil. Sel bakteri yang berwarna merah menunjukkan bahwa Pseudomonas aeruginosa ATCC 27833 adalah bakteri Gram negative. Perbedaan warna pada hasil pewarnaan Gram bakteri Gram positif dengan bakteri Gram negatif dikarenakan kedua jenis bakteri tersebut memiliki struktuk dinding sel yang berbeda(Fitri L, 2011). Gram positif memiliki lapisan peptidoglikan yang lebih tebal, sedangkan pada Gram negatif memiliki lapisan fosfolipid yang lebih tebal, sehingga ketika ditambahkan Gram C (larutan alkohol) dapat melunturkan warna pertama (kristal violet) yang terikat pada sel bakteri Gram negatif, sedangkan pada Gram postif zat warna pertama tidak dapat luntur dengan adanya penambahan Gram C. Lunturnya warna pertama tersebut dapat membuat bakteri menyerap zat warna kedua (safranin) sehingga hasil akhir akan terlihat bakteri Gram negative yang berwarna merah(Dan et al., 2015).

Hasil positif pada Pseudomonas Selective Agar (PSA) dapat diketahui jika pada bakteri tersbut memiliki pigmen piosianin ataupun pigmen pioverdin(Sulviana AW, Puspawati N, 2017). Pigmen tersebut dapat terbentuk dikarenakan adanya magnesium klorida dan kalium sulfat yang terkandung dalam PSA. Pseudomonas aeruginosa ATCC 27833 dalam media PSA akan menunjukkan penampakan koloni halus, bulat, dengan fluorescence yang kehijau-hijauan dikarenakan adanya pigmen pioverdin(paath JM, 2014) .

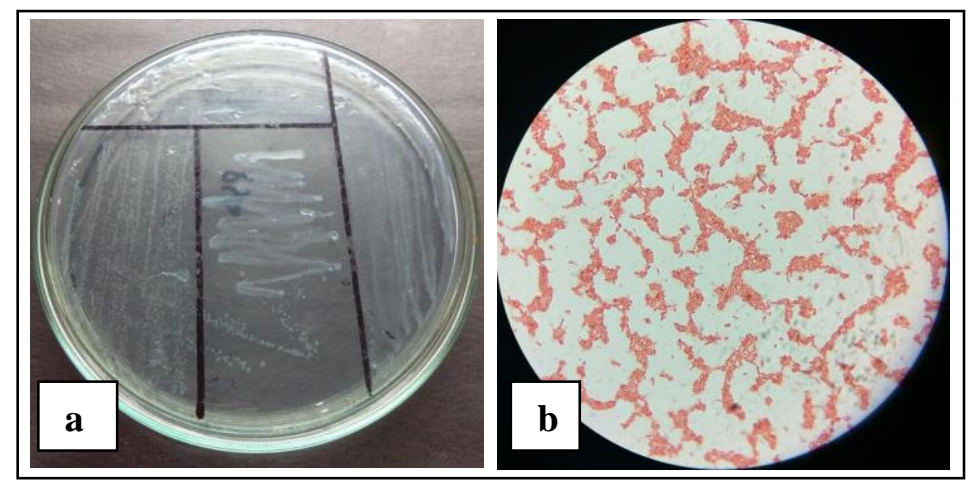

Gambar 2. Hasil Identifikasi Pseudomonas aeruginosa ATCC 27833: a) bakteri pada media PSA; b) pewarnaan Gram dengan perbesaran 1000X.

\section{Uji Aktivitas Antibakteri}

Uji aktivitas antibakteri dilakukan menggunakan metode dilusi cair, sebelum melakukan uji dilusi, maka dilakukan pembuatan suspensi bakteri uji dan kekurahan suspensi masing-masing bakteri uji distandarkan dengan standar kekeruhan McFarland 0.5. Tujuan penyetandaran ini adalah untuk mengontrol jumlah bakteri uji yang akan digunakan pada metode dilusi cair, kekeruhan McFarland 0.5 dianggap sama dengan kekeruhan bakteri sejumlah $1.5 \times 10^{8}$ $\mathrm{cfu} / \mathrm{ml}$ (Sulviana AW, Puspawati N, 2017). Metode dilusi cair ini dipilih karena dapat digunakan untuk menentukan nilai KHM dan KBM dari ekstrak daun suruhan terhadapat bakteri uji(Prihantoro T, Indra R, 2006).

Konsentrasi hambat minimum (KHM) dapat diketahui dengan cara melihat adanya kekeruhan (ada pertumbuhan bakteri) dan kejernihan (pertumbuhan bakteri yang terhambat) pada media dilusi yang telah ditambahkan dengan ekstrak dan suspensi bakteri yang diinkubasi salama 24 jam. Nilai KHM dapat ditentukan dengan cara melihat larutan dilusi yang masih jernih dengan konsentrasi ekstrak terkecil. Hasil uji dilusi yang telah dilakukan untuk bakteri Pseudomonas aeruginosa ATCC 27833 menunjukkan pada semua seri konsentrasi tidak dapat diamati kejernihan sampelnya. Hal tersebut dikarenakan ekstrak yang terlalu pekat dan berwarna hijau tua, sehingga semua sampel berwarna gelap dan tidak dapat diamati kejernihannya. Konsentrasi yang terlalu tinggi dan warna ekstrak yang cukup gelap, mempersulit pengamatan kejernihan tabung dilusi pada masing-masing konsentrasi. 
Penentuan nilai KHM untuk ekstrak suruhan sebaiknya menggunakan metode lain seperti, metode mikro dilusi dimana konsentrasi ekstrak dapat diturunkan sampai pada tingkat ppm dan dapat menggunakan metode difusi cakram (Prihantoro T, Indra R, 2006).

Tabel 1. Penentuan nilai Konsentrasi Hambat Minimum (KHM)

\begin{tabular}{|c|c|c|c|c|c|c|c|c|c|c|c|}
\hline \multirow{2}{*}{ Replikasi } & \multicolumn{9}{|c|}{ Konsentrasi (\%) } & \multirow[b]{2}{*}{$\mathbf{K}+$} & \multirow[b]{2}{*}{ K- } \\
\hline & 50 & 25 & 12.5 & 6.25 & 3.12 & 1.56 & 0.78 & 0.39 & 0.19 & & \\
\hline 1 & TT & TT & TT & TT & TT & TT & TT & TT & TT & + & - \\
\hline 2 & TT & TT & TT & TT & TT & TT & TT & TT & TT & + & - \\
\hline 3 & TT & TT & TT & TT & TT & TT & TT & TT & TT & + & - \\
\hline
\end{tabular}

Keterangan: TT = Tidak Terlihat; K+ = Kontrol positif (suspensi bakteri); K- = Kontrol negatif (BHI), + = Ada pertumbuhan bakteri, - = Tidak ada pertumbuhan bakteri

Penentuan konsentrasi bunuh minimum (KBM) dilakukan dengan cara menanam pada media selektif hasil dilusi cair yang masih terlihat jernih, tetapi karena pada perlakuan tidak ada yang terlihat jernih dikarenakan ekstrak terlalu pekat maka semua konsentrasi digoreskan pada media selektif yaitu, PSA untuk Pseudomonas aeruginosa ATCC 27833 dan diinkubasi selama 24 jam. Hasil yang positif ditunjukkan dengan adanya pertumbuhan bakteri dengan ciri spesifik pada media Pseudomonas selective agar berupa fluorescence berwarna hijau disekeliling koloni bakteri.

Tabel 2. Penentuan nilai Konsentrasi Bunuh Minimum (KBM)

\begin{tabular}{ccccccccccccc}
\hline \multirow{2}{*}{ Replikasi } & \multicolumn{10}{c}{ Konsentrasi (\%) } & \multirow{2}{*}{ K+ } & \multirow{2}{*}{ K- } \\
\cline { 2 - 10 } & $\mathbf{5 0}$ & $\mathbf{2 5}$ & $\mathbf{1 2 . 5}$ & $\mathbf{6 . 2 5}$ & $\mathbf{3 . 1 2}$ & $\mathbf{1 . 5 6}$ & $\mathbf{0 . 7 8}$ & $\mathbf{0 . 3 9}$ & $\mathbf{0 . 1 9}$ & & - \\
2 & - & - & + & + & + & + & + & + & + & + & - \\
3 & - & - & + & + & + & + & + & + & + & + & - \\
\hline \hline
\end{tabular}

Keterangan: $\mathrm{K}+=$ Kontrol positif; K- = Kontrol negatif; + = Ada pertumbuhan bakteri; - = Tidak ada pertumbuhan bakteri

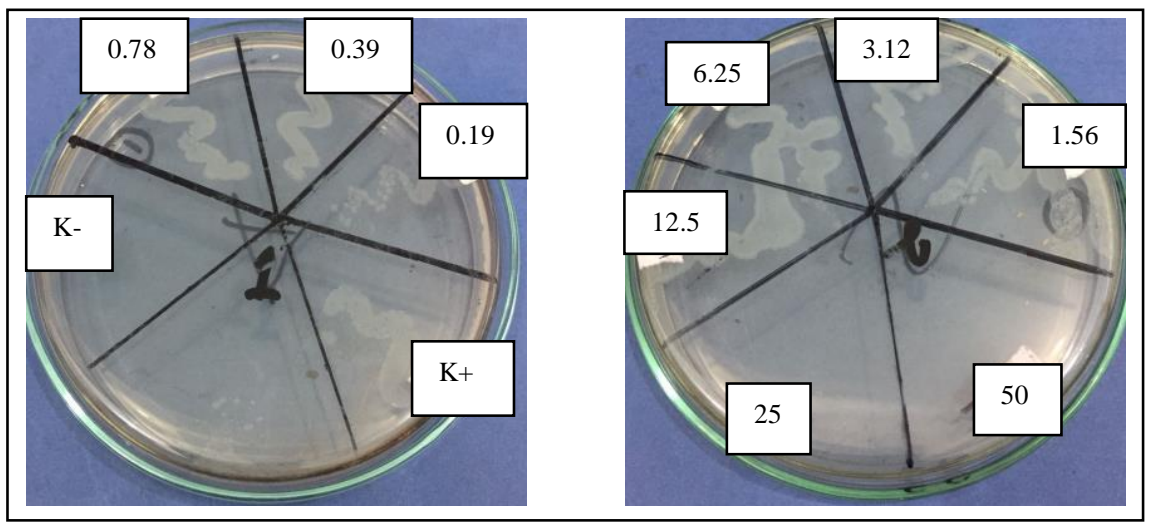

Gambar 3. Hasil goresan larutan dilusi pada media PSA

Hasil pengamatan menunjukkan bahwa nilai KBM untuk Pseudomonas aeruginosa ATCC 27833 adalah $25 \%$. Artinya pada konsentrasi $25 \%$ ekstrak daun suruhan sudah dapat membunuh bakteri Pseudomonas aeruginosa ATCC 27833. Aktivitas antibakteri ini disebabkan karena tanaman suruhan menghasilkan beberapa senyawa metabolit seperti: flavonoid, fenolik, saponin, terpenoid, steroid(Peperomia et al., 2018). Flavonoid dapat mengganggu permeabilitas sel bakteri, dengan cara membentuk kompleks protein yang mengganggu integritas membran sel bakteri (Karlina et al., 2005). Saponin merupakan zat aktif yang dapat meningkatkan permeabilitas membran sel yang menyebabkan hemolisis sel sehingga dapat membuat lisis atau pecahnya membran sel bakteri (Buah \& Gardnia, 2010).

Tanaman suruhan memiliki kandungan lain seperti polifenol dan alisin. Polifenol mampu merusak membran sel, mendenaturasi protein, dan menginaktifkan enzim sehingga dinding sel bakteri akan mengalami penurunan 
permeabilitas yang dapat mengganggu pertukaran zat yang dibutuhkan untuk metabolisme. Sementara alisin merupakan senyawa organosulfur yang dapat menghambat proses pertumbuhan ataupun reproduksi bakteri dengan cara menyerang katalisator enzim dari dalam sel bakteri (Dandirwalu, 2015).

\section{Simpulan}

Ekstrak etanol daun suruhan (Peperomia pellucida L. Kunth) memiliki aktivitas antibakteri terhadap Pseudomonas aeruginosa ATCC 27833 dengan Konsentrasi Bunuh Minimum (KBM) sebesar 25\% atau 0,25 $\mathrm{g} / \mathrm{mL}$. Penelitian lanjutan perlu dilakukan isolasi senyawa antibakteri berupa: flavonoid, fenolik, saponin, terpenoid, steroid untuk mendapatkan antibakteri yang lebih efektif.

\section{Daftar Pustaka}

Article, O., Biswal, I., Arora, B. S., \& Kasana, D. 2014. Incidence of Multidrug Resistant Pseudomonas Aeruginosa Isolated from Burn Patients and Environment of Teaching. 8(5), 5-8. https://doi.org/10.7860/JCDR/2014/7483.43 83

Brooks, Geo F . Butel, Janet. Morse, S. A. 2004. Mikrobiologi Iftdokteran (Vol. 23).

Buah, K., \& Gardnia, M. 2010. Ujiaktivitas Antibakteri Ekstrak Kulit Buah Manggis (Gardnia mangostana Linn). XX(30), 65-69.

Dan, I., Bakteri, I., Laktat, A., Buah, D., \& Mangifera, M. 2015. Isolasi dan Identifikasi Bakteri Asam Laktat (Bal) Dari Buah Mangga ( Mangifera indica L . ). 1(2), 159163.

Dandirwalu, E. 2015. Uji Daya Hambat Ekstrak Etanol Suruhan ( Piperumia pellucida L . H . B Kunth) terhadap Pertumbuhan Bakteri Staphylococcus aureus Secara In-Vitro. 2, 8-14.

Fitri L, Y. Y. 2011. Isolasi dan Pengamatan Morfologi Koloni Bakteri Kitinolitik. Jurnal Ilmiah Pendidikan Biologi, 3(2), 20-25.

Helmi, A., Nelmi, A., Dian, H., \& Rosalinda, R. 2006. Standarisasi ekstrak etanol Daun Eugenia cumini Merr. J. Sains Tek. Far, 11(2), 88-93.
Karlina, C. Y., Ibrahim, M., \& Trimulyono, G. 2005. Aktivitas Antibakteri Ekstrak Herba Krokot ( Portulaca oleracea L .) terhadap Staphylococcus aureus dan Escherichia coli.

paath JM, R. M. 2014. Aplikasi Trichoderma koningii dan Pseudomonas berfluoresensi untuk Pengendalian Penyakit Cabai di Minahasa, Sulawesi Utara. Jurnal Fitopatologi Indonesia, 10(4), 133-137. https://doi.org/10.14692/jfi.10.4.133

Pagani, L., Colinon, C., Migliavacca, R., Labonia, M., Docquier, J. D., Nucleo, E., Spalla, M., Bergoli, M. L., \& Rossolini, G. M. 2005. Nosocomial outbreak caused by multidrugresistant Pseudomonas aeruginosa producing IMP-13 metallo- $\beta$-lactamase. Journal of Clinical Microbiology, 43(8), 3824-3828. https://doi.org/10.1128/JCM.43.8.38243828.2005

Pasril, Y., Yuliasanti, A., \& Umy, G. F. 2014. Daya Antibakteri Ekstrak Daun Sirih Merah ( Piper Crocatum ) terhadap Bakteri Enterococcus Faecalis sebagai Bahan Medikamen Saluran Akar dengan Metode Dilusi Anti-Bacterial Power of Red Batel Leaves ( Piper Crocatum ) to Enterococcus Faecalis Bacteria as. IDJ, 3(1), 88-95.

Peperomia, S., Kunt, L., Abriyani, E., \& Si, M. 2018. Identifikasi sederhana metabolit sekunder tumbuhan sasaladahan. Pharma Xplore : Jurnal Ilmu Farmasi, 3(1), 164169.

Prihantoro T, Indra R, S. 2006. Efek Antibakteri Ekstrak Kulit Buah Delima ( Punica granatum) Terhadap Shigella dysentriae Secara In Vitro. Kedokteran Brawijaya, XXII, 101-104.

Radji, M., Fauziah, S., \& Aribinuko, N. 2011. Antibiotic sensitivity pattern of bacterial pathogens in the intensive care unit of Fatmawati Hospital, Indonesia. Asian Pacific Journal of Tropical Biomedicine, 1(1), 39-42. https://doi.org/10.1016/S22211691(11)60065-8

Rukmono, P., \& Zuraida, R. 2013. Uji Kepekaan Antibiotik Terhadap Pseudomonas aeroginosa Penyebab Sepsis Neonatorum. 14(5), 332-336.

Sulviana AW, Puspawati N, R. R. 2017. Identifikasi Pseudomonas aeruginosa dan Uji Sensitivitas terhadap Antibiotik dari Sampel Pus Infeksi Luka Operasi di RSUD Dr. Moewardi. 10(02), 18-24.

Utami, E. R. 2002. 124 antibiotika, resistensi, dan 
rasionalitas terapi. 124-138.

Vahdani, M., Azimi, L., Asghari, B., Bazmi, F., \& A, R. L. 2012. Phenotypic Screening Of Extended-Spectrum $\beta$-Lactamase And Metallo- $\beta$-Lactamase In Multidrug-Resistant Pseudomonas aeruginosa From Infected Burns. XXV(June), 78-81.

Wei, L. S., Wee, W., Yong, J., Siong, F., \& Syamsumir, D. F. 2011. Characterization of
Anticancer , Antimicrobial, Antioxidant Properties and Chemical Compositions of Peperomia pellucida Leaf Extract. 3-7.

Wulandari, D., \& Purwaningsih, D. 2016. Uji Aktivitas Antibakteri Ekstrak Etanol Daun Suruhan ( Peperomia pellucida L . Kunth ) Terhadap Bakteri Shigella dysentriae. Jurnal Farmasi Indonesia, 13(2), 171-177. 